\title{
Lembrança de Haroldo Maranhão
}

\author{
Jorge Henrique BASTOS ${ }^{*}$
}

Os primeiros anos da década de 80, no Brasil, foram de movimentações políticas que marcaram o país. Dois fatos emblemáticos desse período foram as eleições diretas que levaram Tancredo Neves a se tornar nosso primeiro presidente, após o período da ditadura militar, e o seu falecimento pouco depois.

Particularmente, eu acabara de mudar para São Paulo, e comecei a trabalhar na editora Martins Fontes, experiência que cumpri e devido aos resultados, fui transferido para gerir a filial carioca da editora paulista.

Antes de arrumar a mala, eu estivera no lançamento do livro de Mário Faustino, que estava fora do mercado há anos e publicado pela extinta Max Limonad. Aí tive o prazer de conhecer o editor Samuel Leon e o Haroldo Maranhão, que se deslocou a São Paulo especialmente para o evento.

Nessa noite, nos aproximamos, eu e Haroldo, por um fato curioso. Fora contratado um ator para fazer a leitura de alguns poemas de Faustino. Contudo, o ator em vez de ler os poemas, começou a falar sobre si mesmo, sobre ser ator e que estava ali para dar o seu melhor. Mas o discurso se estendia, de maneira incômoda e nada digna de Faustino. Num dado momento o interrompi, disse-lhe que sabíamos bem o que era a arte de interpretar, mas ele estava ali para reproduzir as palavras de um grande poeta, que merecia toda a atenção. Acrescentei ainda que Paulo Autran, quando dizia um poema, se "entregava" a esse poeta, não procurava se sobrepor a ele. O ator começou uma discussão. Deixei-o falando, enquanto o burburinho aumentava.

Em seguida, Haroldo de Campos, que também estava presente, insurgiu-se e falou severamente que o ator deveria só ler os poemas, o que acabou por fazer de maneira inepta, sem entusiasmo ou profissionalismo, e se retirou em seguida. Várias pessoas pediram para ler poemas. O Haroldo de Campos leu "Balada", aquele poema

\footnotetext{
* Jornalista, tradutor e editor. Publicou Poesia Coletiva (Belém, 1985, com Vasco Cavalcante, Zé Minino e Rey Vinas) A Idade do Sol (Fenda, LX, 1998), Hemorragia (São Paulo, 2012). Organizou a antologia Poesia Brasileira do Século XX - dos modernistas à actualidade (Lisboa, 2002), O Corpo O Luxo A Obra de Herberto Helder (São Paulo, 1999). Traduziu O Renascimento - ensaios sobre poesia e arte de Walter Pater (Iluminuras), O Retorno do Nativo de Thomas Hardy (Martin Claret, 2017). Colabora em jornais e revistas como CULT, Brasileiros e Folha de São Paulo.
} 
com que o Glauber epigrafou seu grande filme, "Terra em Transe"; outro leitor leu o belíssimo "Vida toda linguagem". E a homenagem acabou bem.

O Haroldo Maranhão se aproximou e começamos a conversar. Percebeu que eu era paraense, e desde essa altura a amizade se criou. Trocamos endereços e contatos. Meses depois, avisei-o que estava de mudança para o Rio.

Cheguei na cidade, em agosto de 1985, e me estabeleci na rua Buarque de Macedo, pequena artéria que acaba no Aterro do Flamengo, em pleno inverno a incomodar o recém-chegado nortista. O Haroldo Maranhão morava quase duas quadras depois da minha rua, bem ao lado do Palácio do Catete.

Guardo estas memórias com um misto de nostalgia e alegria, já que acabei por ficar próximo do Haroldo, o que me ajudou a preencher a ausência da família e de amigos de Belém.

O Haroldo passou a me visitar na sede da editora, na rua da Alfândega, perto da Rio Branco, onde conversávamos sobre livros; apresentava-o a outros tantos amigos que ia fazendo; saíamos para almoçar ou tomar um chopp (ele tomava mesmo só um).

Eu o visitava aos fins de semana, no apartamento do Aterro, onde me mostrava sua tão amada biblioteca, toda encadernada; ou os santos barrocos que colecionava. Fazia questão de assinalar que a foto do Benedito Nunes, disposta entre algumas dessas esculturas, era o único local onde poderia ficar. O carinho e a delicadeza que Haroldo dedicava ao seu amigo de tantas aventuras se expunha com toda verdade.

Nesses momentos, minha curiosidade entrava em ebulição, e lhe perguntava sobre o grupo do Café Central; sobre o suplemento da Folha do Norte; queria saber do Max Martins, Faustino, do Francisco Paulo Mendes. Haroldo lembrava-se de tudo, fazia comentários irônicos sobre alguns personagens; se entusiasmava ao lembrar que publicaram autores cuja relevância indiscutível demonstrava a seriedade do espaço literário que ele conquistara no célebre jornal de Paulo Maranhão.

Uma lembrança que o deixava feliz, foi quando Sartre e Simone de Beauvoir passaram por Belém, nos anos 60 , no périplo que o casal francês fez pelo Brasil. O filósofo participou numa sessão de autógrafos, na livraria D. Quixote. Haroldo e sua companheira, que falava fluentemente francês, passearam com eles, mostrando a Belém que a riqueza da borracha erguera. 
Recordo bem que observava o olhar do Haroldo, que parecia deter um brilho remoto, solitário, e eu entendia como viver longe da cidade onde nascera foi algo que o marcou sempre.

Referia-se sobre a amizade com Benedito Nunes como algo que estava além do laço fraternal. Quando Benedito ia ao Rio, Haroldo logo me ligava e combinávamos um almoço. Encontrávamo-nos na livraria da editora, não antes de o Benedito separar pilhas de livros. Seguíamos depois pela Miguel Couto; passávamos pela Livraria Padrão, com seu friso inferior de azulejos portugueses. Abraçávamos o seu Alberto Lacerda e íamos para o restaurante, onde um carneiro com molho de hortelã nos aguardava. Enquanto andávamos, pensava que ali estavam dois escritores de importância categórica para a literatura paraense, mas que haviam suplantado os limites regionais. E eram meus amigos.

Minha vida no Brasil estava prestes a se transformar mais uma vez, pois outra mudança ocorreria em 1989, quando casei e mudei para Lisboa. Haroldo foi dos amigos que de imediato apoiou minha decisão, demonstrando sua felicidade com palavras de alento e estímulo.

Haroldo fora me buscar em minha casa para me levar à cerimônia civil. Nesse dia, ele me entregou um presente: uma gravura emoldurada de Belém, do primeiro quartel do século XIX, uma vista da cidade a partir da Baía do Guajará. Lembro todas as palavras que me disse naquele dia: "Jorge, não interessa onde estivermos, ela estará sempre dentro de nós".

Já morando em Lisboa, toda vez que olhava a gravura as palavras do Haroldo soavam dentro de mim, tal como soou o momento de regressar ao Brasil após a longa temporada lusitana.

Jamais esqueço o dia em que abri o pacote contendo o grande romance Cabelos no Coração. Eu achava que depois de $O$ Tetraneto del Rei, ele não conseguiria se superar. Ledo engano. Haroldo mergulhou de novo com sua verve mordaz, burlesca e ergueu um monumento literário em forma de biografia apócrifa do jornalista Felipe Patroni. Fiquei ainda mais sensibilizado ao topar com a homenagem que Haroldo fez a mim, ao me introduzir num dado momento da trama do livro.

Aliás, esse livro oculta uma série de referências, tanto emotivas e fraternais, como críticas e cizânias de estimação. Creio que ainda não há um estudo capaz de 
desenredar essa trama. Se alguém, um dia, se deter sobre isso, há de contar um pouco a história lateral da cultura no Pará. Tal como no livro Rio de Raivas, o mundo provinciano da política paraoara é caçoado de maneira modelar.

Desde essa época, e após ler e refletir várias vezes, intuí que nossa produção romanesca possui dois polos incontornáveis: Dalcídio e Haroldo. Na obra de ambos a região Norte adquire uma paleta absolutamente genuína. A estética dos dois escritores é determinante, telúrica. Mas, enquanto Dalcídio parte do interior para a cidade, Haroldo parte da cidade para o mundo. Em Dalcídio, a realidade se estampa com toda tensão e vigor. Já Haroldo, manipula a história e a reinventa através do simulacro sarcástico sem precedentes. Mas chega a ser um sarcasmo melancólico que se desprende das páginas.

O verão de 2004, em Portugal, foi rigoroso. Um calor intenso e seco acentuava a paisagem. Naquele dia de julho, como sempre fazia, liguei o computador, flanei pelos jornais europeus, em seguida os brasileiros.

Quando se vive fora do país, estamos sempre à espera de notícias que podem nos assombrar. As letras da manchete desenhavam o nome do Haroldo. Naquele mês, os portugueses perderam Sophia de Mello Breyner e o guitarrista Carlos Paredes, nomes que me ajudaram a amar a cultura portuguesa.

Eu, à distância, perdia o Haroldo Maranhão, sem poder me despedir dele, sem ter dito que seus livros mantiveram viva em mim a cultura em que nasci, sabendo entendê-la e amá-la mesmo vivendo distante dela.

Corri até a sala, parei diante da gravura, tirei-a da parede e fiquei olhando.

Tempos depois, quando já havia regressado ao Brasil, em outubro de 2007, escrevi o poema que precisava ser escrito, a despedida que estava por fazer. E só então, quase ensaiando um sorriso, vislumbrei a baía do Guajará e repeti: Sim, Haroldo, tinhas toda razão. 


\section{PERTENÇA}

Em memória de Haroldo Maranhão

Doía a mão decepada

que tanto manobrou

a obsessão: cruciar palavras.

- raiva escárnio cabelos coração -

$\mathrm{Na}$ terra que habitou

as árvores formam o fecho da cúpula

de uma catedral que já não irá visitar,

ela cerca bichos, homens, água.

Vem daí o cheiro de madrugada,

de fruta ácida caída no chão.

Depois o rio reboca o terror,

a maresia erra, se alastra,

cobre a visão, viola as tardes,

estiola a infância

e anestesia o sono daqueles

para quem sonhou.

A cidade continuará sonâmbula, os fantasmas entrando nos casarões, no tumor das árvores arqueadas

Revista Moara, n. 53, ago-dez 2019 ISSN: 0104-0944 
sob o torpor do meio-dia.

O musgo escorando

o tempo na parede.

$\mathrm{O}$ vento alisa as folhas,

lustra as esquinas de lioz,

bate nas janelas altas,

enche as cúpulas de ausência.

Nem os caranguejos

irão levantar suas pinças

para saudá-lo,

estará anônimo

com a cólera silenciosa.

Ele soube ler

no fundo da água marajoara

como se pode pertencer

ao que inutilmente nos recusa. 